\title{
1 Climate changes caused by degassing of sediments 2 during the emplacement of large igneous provinces
}

\author{
Clément Ganino and Nicholas T. Arndt \\ Laboratoire de Géodynamique des Chaînes Alpines, Université Joseph Fourier de Grenoble, \\ CNRS, 1381 rue de la piscine 38400 Saint Martin d'Hères, France \\ Corresponding author: clement.ganino@ujf-grenoble.fr
}

\begin{abstract}
Most mass extinctions during the last $500 \mathrm{~m}$.y. coincide with eruptions of large igneous provinces (LIP): the Cretaceous-Tertiary extinction was synchronous with the Deccan flood volcanism, Permian-Triassic extinction with the eruption of the enormous Siberian Traps, and End-Guadalupian extinction with the Emeishan volcanic province. The causal link remains disputed, however, and many LIPs apparently had no significant impact on the biosphere. Here we show that a key control on the destructive consequences of LIP emplacement is the type of sedimentary rock in basins beneath the flood basalts. Contact metamorphism around intrusions in dolomite, evaporite, coal or organic-rich shale generates large quantities of greenhouse and toxic gases $\left(\mathrm{CO}_{2}, \mathrm{CH}_{4}\right.$, $\mathrm{SO}_{2}$ ) which subsequently vent to the atmosphere and cause global warming and mass extinctions. The release of sediment-derived gases had a far greater impact on the environment than the emission of magmatic gases.
\end{abstract}

Keywords: large igneous province, mass extinction, contact metamorphism, sedimentary wall-rock, Emeishan

\section{Introduction}

During a mass extinction, taxa from a broad range of habitats and from throughout the world disappear within a geologically brief interval ( 1Ma) (Hallam and Wignall, 1997). Vogt (1972) noted that the end-Cretaceous mass extinction was synchronous with eruption of the Deccan Traps flood basalts and Courtillot and Renne (2003) have catalogued many other coincidences between mass extinction and flood volcanism. In early papers the extinctions were attributed to poisoning (Vogt 1972), global warming (Jenkyns 1999) or global cooling (Budyko and Pivivariva, 1967; Axelrod, 1981) caused by the emission of volcanic gases. A problem with this interpretation is the absence of a good correlation between the volume of erupted basalt and the impact on the biosphere, as shown in Fig. 1. The eruption of the Siberian and Emeishan basalts coincide with major extinction but the Karoo basalts, for example, can be linked only to a period of global warming (McElwain et al., 1999). Nor does the latitude at the time of eruption, which influences the efficiency of atmospheric distribution of emitted gases and aerosols, correlate with the intensity of the environmental crisis.

Here we develop the ideas of Svensen et al. (2004, 2007) and Retallack and Jahren (2008) and propose that the intensity of global climate changes may be related to the type of rocks invaded by subvolcanic intrusive complexes, rather than to the volume or nature of the degassing lava. We present new data from contact aureoles surrounding intrusions of the Emeishan province in China, a province that coincides with the major 
end-Guadalupian environmental crisis, and we link the environmental change to massive release of $\mathrm{CO}_{2}$ from the dolomites and organic-rich carbonates of the underlying sedimentary basin. We contrast this setting with the more benign effects of other LIPs which were emplaced upon older basalts, crystalline basement or sedimentary rocks low in carbon and sulfur.

\section{How do LIPs change the climate and cause mass extinctions?}

Major volcanic eruptions impact the environment in many ways: ash and sulphuric acid aerosols lead to cooling, greenhouse gases like $\mathrm{CO}_{2}, \mathrm{CH}_{4}$ cause global warming; $\mathrm{SO}_{2}$ causes acid rain; $\mathrm{F}$ and other halogens poison plants and animals (see Thordarson et al., 1996; Wignall, 2001 for a review). In all the LIPs shown in Figure 1, the dominant magma is tholeiitic basalt which contains relatively low contents of magmatic gases. Caldeira and Rampino (1990) estimated that the preruptive $\mathrm{CO}_{2}$ concentration of the Deccan magmas ( $0.2 \mathrm{wt} \%)$ was sufficient to cause only modest global warming; Self et al. (2006) confirmed that the mass of volcanic $\mathrm{CO}_{2}$ was small compared with the $\mathrm{CO}_{2}$ already present in the atmosphere and they suggested that climate perturbations were related to the emission of volcanic $\mathrm{SO}_{2}$.

Many LIPs also contain minor alkalic magmas, volatile-rich magmas that may have released larger quantities of volcanic gases, but there is little evidence that those provinces with higher-than-normal alkali magma contents (e.g. Ethiopia) had a disproportionate environmental impact (Courtillot and Renne, 2003). For reasons such as these we explore the hypothesis that the killer mechanism that drives global warming and mass extinctions is to be found in the sedimentary horizons beneath the flood basalts.

\section{A case study: sediment degassing during the emplacement of the Emeishan LIP}

The current, post-erosional exposure the Emeishan LIP in SW China is relatively small but the volcanic province may initially have covered $>0.5 \mathrm{Mkm}^{2}$ (Courtillot and Renne 2003). Its emplacement coincides with (1) a major sea-level fall (Hallam and Wignall, 1999), (2) a negative ${ }^{13} \mathrm{C}$ excursion (Retallack et al., 2006) and (3) the major end-Guadalupian biological crisis when $\sim 35 \%$ of all genera became extinct (Bowring et al., 1998, Zhou et al., 2002). Magmas of the Emeishan LIP intruded Proterozoic to Silurian dolostones, marls and shales of the Sichuan Basin.

Ganino et al. (2008) showed that the 2000 -m thick Panzhihua gabbroic sill, one of many in the Emeishan province, developed a 300 m-thick contact aureole as it intruded Proterozoic dolomites. The dominant rock type in the aureole is marble containing about $30 \%$ brucite, the hydration product of periclase. The latter mineral formed during prograde metamorphism of dolomite, a process that yields abundant $\mathrm{CO}_{2}$. The trace element composition of a brucite marble immediately adjacent to the intrusive contact shows evidence of partial melting of carbonates; farther from the contact, metamorphism of impure limestones formed calc-silicates. Both processes released additional $\mathrm{CO}_{2}$. Several hundred kilometres to the north-west of the Emeishan basalts, shales and limestones of the Sichuan Basin contain gas and petroleum deposits (Wei et al., 2008) and the metamorphism of hydrocarbons in contact aureoles may have released $\mathrm{CO}_{2}$ and $\mathrm{CH}_{4}$. In the following section we quantify the amounts of $\mathrm{CO}_{2}$ released from magmatic and sedimentary sources. 


\section{Quantification of gas release during emplacement of the 94 Panzhihua intrusion}

Following Self et al.'s (2006) estimation of $\mathrm{CO}_{2}$ release from Deccan volcanism, we estimate that $\sim 2 \mathrm{Gt}$ of magmatic $\mathrm{CO}_{2}(=0.55 \mathrm{Gt} \mathrm{C})$ was released from the $180 \mathrm{~km}^{3}$ of magma in the Panzhihua intrusion.

Three main reactions took place during the metamorphism of Panzhihua wall rocks, depending on the temperature. We first focus on the intermediate-temperature periclase-forming reaction dolomite $=$ periclase + calcite $+\mathrm{CO}_{2}$. From the reaction we calculate that $240 \mathrm{~g}$ of $\mathrm{CO}_{2}$ are released per kilogram of dolomite. From the dimensions of the lower contact aureole (19 km long, $300 \mathrm{~m}$ wide and an assumed $3 \mathrm{~km}$ in depth), we calculate its mass as $\sim 47 \mathrm{Gt}\left(\right.$ density $=2700 \mathrm{~kg} \cdot \mathrm{m}^{-3}$ ) to give a total of $11.2 \mathrm{Gt}$ of $\mathrm{CO}_{2}$ (or $3.1 \mathrm{Gt} \mathrm{C}$ ). An equivalent mass of $\mathrm{CO}_{2}$ probably was released by periclase formation in an upper contact aureole, which is not preserved due to faulting.

We can use the presence of periclase, which formed at $700^{\circ} \mathrm{C}$ in samples collected $300 \mathrm{~m}$ from the intrusive contact, to define the temperature profile in the aureole (Fig. 2). We modelled the development of the aureole assuming that basaltic magma continuously flowed through the sill to maintain a temperature of $1200^{\circ} \mathrm{C}$ at the contact. In a simple conductive model, the profile requires 2500 years to form; when fluid advection is taken into account, the time is shorter. Such a temperature profile explains the presence of melted carbonates adjacent to the intrusion $\left(\sim 1200^{\circ} \mathrm{C}\right)$ and the presence of periclase, which forms at $\sim 700^{\circ} \mathrm{C}$ at a depth $300 \mathrm{~m}$ below the lower contact.

We now use this profile to estimate the quantities of gas released by high- and lowtemperature reactions (see supplementary material). The calculation is only approximate because we have relatively little information about the exact geometry and structure of the contact aureole, but it is sufficient to provide a first-order estimate. High-temperature reactions such as the assimilation and partial melting of dolostone yield abundant $\mathrm{CO}_{2}$ but only within a few metres of the contact. An indication of the amount of $\mathrm{CO}_{2}$ that might be released by the assimilation of wall-rock in mafic magmas is provided by Iacono Marziano et al. (2007) who calculated that lavas of Mt Vesuvius had assimilated $15-17 \mathrm{wt} \%$ of limestone.

Calc-silicates form from impure marble between 450 and $500^{\circ} \mathrm{C}$ and these reactions release between 220 and $290 \mathrm{~g}$ per $\mathrm{kg}$ of rock. Total degradation of hydrocarbons at temperatures above $300^{\circ} \mathrm{C}$ would have released additional methane and $\mathrm{CO}_{2}$. The large range of concentration and maturation of organic carbon, preclude any precise quantification of the mass of $\mathrm{CO}_{2}$ released during low temperature degradation of hydrocarbon, but some limits can be calculated. If the wall rocks contained a low content of organic carbon $(0.01 \mathrm{wt} \%)$ the input $(0.02 \mathrm{Gt} \mathrm{C})$ would be negligible but if they contained $4 \mathrm{wt} \%$ organic carbon, as observed in source rock of the Sichuan Basin (Wei et al., 2008), then the mass of $\mathrm{CO}_{2}$ would be $8.1 \mathrm{Gt} \mathrm{C}$, similar to that released from the periclase reaction.

Given these results, we estimate that a total of at least $22 \mathrm{Gt}$ of $\mathrm{CO}_{2}$ from the periclase reaction, and up to $\sim 52 \mathrm{Gt}$ equivalent $\mathrm{CO}_{2}(=14.1 \mathrm{Gt} \mathrm{C})$ if the wall-rock contained large amount of organic carbon, was formed from the contact aureoles. These values can be compared with the $\sim 2 \mathrm{Gt} \mathrm{CO}_{2}(=0.54 \mathrm{Gt} \mathrm{C})$ released from the magma. At the intrusion scale, the mass of sediment-derived carbon is some 11 to 26 times greater than the mass of magmatic carbon. 
140 Because of intense Himalaya-related deformation it is difficult to estimate the total amount of sedimentary rock of the Sichuan Basin that was affected by metamorphism. Taking as a model the better-preserved lava piles and sedimentary basins in the Siberian and Karoo volcanic provinces (Czamanske et al., 2002; Chevallier and Woodford, 1999), we assume that about half of the volume of the Emeishan volcanic pile was emplaced as shallow-level intrusions. Courtillot and Renne (2002) calculate that the total volume of the erupted basalt in the Emeishan LIP was $\sim 1 \mathrm{Mkm}^{3}$ and, following Self et al.'s (2006) estimation for the Deccan, such a volume of magma would release $11200 \mathrm{Gt}$ of $\mathrm{CO}_{2}(=3057 \mathrm{Gt} \mathrm{C})$. Magma in intrusions emitted an additional $5600 \mathrm{Gt}$ of $\mathrm{CO}_{2}$ bringing the total to $16800 \mathrm{Gt}$ of $\mathrm{CO}_{2}$ or $4585 \mathrm{Gt}$ of $\mathrm{C}$.

If the Panzhihua intrusion is representative of an average sill in the intrusive complex below the lava pile, 11 to 26 times more metamorphic $\mathrm{CO}_{2}(5600 * 11=61600$ $5600 * 26=145600 \mathrm{Gt} \mathrm{CO}_{2}$ ) was released from contact aureoles. Thus at the LIP scale, the mass of sediment-derived $\mathrm{CO}_{2}$ is about 3.6 to 8.6 times larger than the mass of magmatic $\mathrm{CO}_{2}$.

\section{Proxies of climate change in Emeishan-age sediments}

Can $\mathrm{CO}_{2}$ released during contact metamorphism of carbonates explain the negative carbon isotope excursion at the end-Guadalupian which is recorded in both marine carbonate and continental organic matter by Retallack et al. (2006)? During the endGuadalupian, the $\delta^{13} \mathrm{C}$ of marine carbonates decreased from about +3 to $-2 \%$, and that of nonmarine clastic organic carbon from about -22 to $-30 \%$ (Retallack et al., 2006). If we suppose that $17000 \mathrm{Gt} \mathrm{C}$ from the destabilisation of dolostone (with $\delta^{13} \mathrm{C}=0$ ) and $22900 \mathrm{Gt} C$ from the metamorphism of organic carbon (with $\delta^{13} \mathrm{C} \sim-22$ ) were added to the ocean-atmosphere, a global negative carbon isotope excursion would result (see supplementary material for details). Atmospheric carbon composition would change from $\delta^{13} \mathrm{C}=-2$ before the degassing to as low as -10.9 after the degassing.

There are few reliable proxies for the climate changes during the emplacement of the Emeishan LIP.

\section{Sediment degassing and mass extinctions}

Figure 2 is a synthesis of the total amount of volatiles released during the contact metamorphism of different types of sedimentary rocks. The inputs that must be considered when evaluating the environment impact of LIP emplacement can be summarized as follows:

- Basalt and granitoids do not release abundant volatiles.

- In most sandstones, the main volatile is water whose release has little effect on global climate.

- Pure limestone contains large amounts of $\mathrm{CO}_{2}$ but the thermal decomposition of limestone into $\mathrm{CaO}$ and $\mathrm{CO}_{2}$ takes place at high temperatures $\left(>950^{\circ} \mathrm{C}\right)$ that are rarely reached in contact aureoles.

- Impure limestones release large amounts of $\mathrm{CO}_{2}$ (up to $29 \mathrm{wt} \%$ ) during the formation of calc-silicates at moderate temperatures of $\sim 450$ to $500{ }^{\circ} \mathrm{C}$.

- Gypsum and anhydrite in evaporites release abundant $\mathrm{SO}_{2}$ (up to $47 \%$ ). This reaction normally happens at high temperatures $\left(1400^{\circ} \mathrm{C}\right)$ that are not observed in contact aureoles, but the reaction proceeds at temperature as low as $615^{\circ} \mathrm{C}$ for impure anhydrite (West and Sutton, 1954). 
- Sulfidic sediments release abundant $\mathrm{SO}_{2}$ at low temperature.

- Organic carbon-rich shales and carbonates release methane and hydrocarbon when heated at relatively low temperature $\left(<300^{\circ} \mathrm{C}\right)$.

- Coal releases abundant $\mathrm{CO}_{2}$ if ignited.

Figure 1 shows that there is no clear link between volume of the LIP and magnitude of mass extinction. Degassing of magmatic volatiles therefore cannot be the sole cause of the environmental changes and mass extinctions and gas release from sediments may be implicated in various ways:

1. The Ontong-Java oceanic plateau, the largest magmatic province, formed in a submarine volcanic setting and is not associated with a large mass extinction. The dominant wall rock is basalt which yields no toxic or greenhouse gases (dehydration of altered basalt has little climatic impact). Eruption into water may have restricted release of gas into the atmosphere.

2. Emplacement of the Deccan traps coincides with the K-T mass extinction (e.g. Courtillot and Renne, 2002). Here the substrate consists of minor clastic sediments and crystalline basement, which do not yield additional volatiles, and a combination of Chixculub meteorite impact (e.g., Alvarez et al. 1980) and the release of magmatic gases (Chenet et al., 2008) may account for the K-T mass extinction.

3. Eruption of the Siberian traps, the largest continental flood basalt province, coincided with the largest known mass extinction. The volume of basalt cannot explain the intensity of the crisis by itself. Intrusions beneath the Siberian traps invaded marls, limestones, sandstones, coal and most significantly, evaporites (Czamanske et al., 2002). The sulphur isotope signature of sulfide ores provides evidence that sulfur from evaporites was assimilated into magma (Ripley et al., 2003). Part of the sulfur contained in the magma was probably released as $\mathrm{SO}_{2}$ during the eruption, and additional $\mathrm{SO}_{2}, \mathrm{CO}_{2}$, the breakdown products of hydrocarbons, would be expelled from the contact aureoles (Retallack and Jahren, 2008). Global dispersion of $\mathrm{SO}_{2}$ from Siberian traps volcanism was aided by the high latitude of these eruptions (e.g., Saunders, 2005).

4. The Emeishan plateau erupted at equatorial latitude and here the consequences were different. The dispersion of $\mathrm{CO}_{2}$ is largely independent of latitude because of the high exchange rate between the stratosphere and the troposphere. We suggest therefore that the coincidence between the Emeishan volcanism and the end-Guadalupian crisis can be explained by the voluminous release of $\mathrm{CO}_{2}$ from the heating of dolomite augmented by $\mathrm{CO}_{2}, \mathrm{SO}_{2}$ and $\mathrm{CH}_{4}$ from evaporites and shales.

In those provinces where the environmental impact was minor, the wall rocks were sandstone, organic-poor shales or granitic basement. Svensen et al. (2007) estimated that up to $27400 \mathrm{Gt}$ may have formed during contact metamorphism of shales and sandstones of the Karoo basin, enough to explain the Early Jurassic global warming but not sufficient to cause a mass extinction. Likewise, the Central Atlantic Magmatic Province coincides with the Triassic-Jurassic mass extinction but the influence of this very large province may have been mitigated by the largely crystalline nature of its wall rocks

\section{Conclusion}

Sedimentary rocks are huge reservoirs of volatiles that are readily released by contact metamorphism. The degassing associated with contact metamorphism is much more voluminous than the degassing of the magma itself. We have identified two major mechanisms responsible for large gas emissions and mass extinctions: (1) the 
destabilization of dolomite, which caused massive $\mathrm{CO}_{2}$ release during the emplacement of Emeishan and other LIPs, (2) the thermal decomposition of anhydrite, salt, limestone, hydrocarbons and coal in other provinces, which provided a toxic cocktail that caused other mass extinctions. Other provinces were emplaced in sterile magmatic or sedimentary rocks and had little to no environmental impact.

\section{Acknowledgements}

We express our gratitude to Henrik Svensen for his constructive comments and his help with the preparation of the manuscript. We also thank Catherine Chauvel, Fernando Tornos, Lukas Baumgartner and Didier Marquer for constructive discussions; Mei-Fu Zhou and Yuxiao Ma for assistance during our field work; and Chris Harris for providing stable isotope analyses. The project was supported by two Egide exchange programs PROCORE (France Hong Kong) and Aurora (France-Norway). Further support was obtained from the French CNRS (DyETI program).

\section{References cited}

252

253

254

255

256

257

258

259

260

261

262

263

264

265

266

267

268

269

270

271

272

273

274

275

276

277

278

279

280

281

282

283

Alvarez, L.W., Alvarez, W., Asaro, F., and Michel, H.V., 1980. Extraterrestrial cause for the Cretaceous Tertiary extinction: Science, v. 208, p. 1095-1108, doi: 10.1126/science.208.4448.1095.

Axelrod, D.I., 1981. Role of volcanism in climate and evolution: Geol. Soc. Am., Spec. Pap. 185, 1-59.

Bowring, S.A., Erwin, D.H., Jin, Y.G., Martin, M.W., Davidek, K., and Wang W., 1998, U/Pb Zircon Geochronology and Tempo of the End-Permian Mass Extinction: Science, v. 280, p. 1039-1045, doi: 10.1126/science.280.5366.1039.

Budyko, M.I., and Pivivariva, Z.I., 1967, The influence of volcanic eruptions on solar radiation incoming to the Earth's surface: Meteorol Gidrol, v. 10, p. 3-7.

Caldeira, K., and Rampino, M.R., (1990), Carbon dioxide emissions from Deccan volcanism and a K/T boundary greenhouse effect: Geophysical Research Letters, v. 17, p. 1299-1302.

Chenet, A.L., Fluteau, F., Courtillot, V., Gérard, M., and Subbarao, K.V., 2008, Determination of rapid Deccan eruptions across the Cretaceous-Tertiary boundary using paleomagnetic secular variation: Results from a 1200-m-thick section in the Mahabaleshwar escarpment: Journal of Geophysical Research v.113, B04101, doi: 10.1029/2006JB004635.

Chevallier, L., and Woodford, A., 1999, Morpho-tectonics and mechanism of emplacement of the dolerite rings and sills of the western Karoo, South Africa: South African Journal of Geology, v. 102, p. 43-54.

Courtillot, V., and Renne, P.R., 2003, On the ages of flood basalt events: Comptes Rendus Geoscience, v. 335, p. 113-140, doi: 10.1016/S1631-0713(03)00006-3.

Czamanske, G.K., Zen'ko, T.E., Fedorenko, V.A., Calk, L.C., Budahn, J.R., Bullock, J.H., Fries, T., King, B.-S., and Siems, D., 2002, Petrographic and geochemical characterization of ore-bearing intrusions of the Noril'sk type. Siberia: With discussion of their origin, including additional datasets and core logs: US Geological Survey Open-File Report: 02-74.

Ganino, C., Arndt, N.T., Zhou, M.F., Gaillard, F., and Chauvel, C., 2008, Interaction of magma with sedimentary wall rock and magnetite ore genesis in the Panzhihua mafic intrusion, SW China, Mineralium deposita, 43, 677-694, doi: 10.1007/s00126-008-0191-5. 
Hallam, A. and Wignall, P.G., 1997, Mass Extinctions and Their Aftermath: Oxford University Press, $334 \mathrm{p}$.

Hallam, A. and Wignall, P.B., 1999, Mass extinctions and sea-level changes: EarthScience Reviews, v. 48, p. 217-250, doi: 10.1016/S0012-8252(99)00055-0.

Iacono Marziano, G., Gaillard, F., and Pichavant, M., 2007, Limestone assimilation by basaltic magmas: an experimental re-assessment and application to Italian volcanoes: Contributions to Mineralogy and Petrology, v. 154, p. 1-20, doi: 10.1007/s00410-007-0267-8.

Jenkyns, H.C., 1999, Mesozoic anoxic events and palaeoclimate: Zentralblatt für Geologie und Paläontologie, p. 943-949.

McElwain, J.C., Beerling, D.J., and Woodward, F.I., 1999, Fossil Plants and Global Warming at the Triassic-Jurassic Boundary: Science, v. 285, p. 1386-1390, doi: 10.1126/science.285.5432.1386.

Retallack, G.J., Metzger, C.A., Greaver, T., Jahren, A.H., Smith, R.M.H., and Sheldon, N.D., 2006, Middle-Late Permian mass extinction on land: Bulletin of the Geological Society of America, v. 118, p. 1398-1411, doi: 10.1130/B26011.1.

Retallack, G.J., and Jahren, A.H., 2008, Methane release from igneous intrusion of coal during late Permian extinction events: The Journal of Geology, v. 116, p. 1-20, doi: $10.1086 / 524120$.

Ripley, E.M., Lightfoot, P.C., Li, C., and Elswick, E.R., 2003, Sulfur isotopic studies of continental flood basalts in the Noril'sk region: implications for the association between lavas and ore-bearing intrusions: Geochimica et Cosmochimica Acta, v. 67, p. 2805-2817, doi:10.1016/S0016-7037(03)00102-9.

Rohde, R.A., and Muller, R.A., 2005, Cycles in fossil diversity: Nature v. 434, p. 208210, doi: 10.1038/nature03339.

Saunders, A.D., 2005, Large Igneous Provinces: Origin and Environmental Consequences: Elements, v. 1, p. 259-263, doi: 10.2113/gselements.1.5.259.

Self, S., Widdowson, M., Thordarson, T., and Jay A.E., 2006, Volatile fluxes during flood basalt eruptions and potential effects on the global environment: A Deccan perspective: Earth and Planetary Science Letters, v. 248, p. 518-532, doi:10.1016/j.epsl.2006.05.041.

Svensen, H., Planke, S., Malthe-Sørenssen, A., Jamtveit, B., Myklebust, R., Eidem, T., and Rey, S.S., 2004, Release of methane from a volcanic basin as a mechanism for initial Eocene global warming: Nature, v. 429, p. 542-545, doi: 10.1038/nature02566.

Svensen, H., Planke, S., Chevallier, L., Malthe-Sørenssen, A., Corfu, B., and Jamtveit, B., 2007, Hydrothermal venting of greenhouse gases triggering Early Jurassic global warming: Earth and Planetary Science Letters, v. 256, p. 554-566, doi: 10.1016/j.eps1.2007.02.013.

Thordarson, T., Self, S., Óskarsson, N., and Hulsebosch, T., 1996, Sulfur, chlorine, and fluorine degassing and atmospheric loading by the 1783-1784 AD Laki (Skaftár Fires) eruption in Iceland: Bulletin of Volcanology, v. 58, p. 205-225, doi: $10.1007 / \mathrm{s} 004450050136$.

Vogt, P.R., 1972, Evidence for global synchronism in mantle plume convection, and possible significance for geology: Nature, v. 240, p. 338-342, doi: 10.1038/240338a0.

Wei, G., Chen, G., Du, S., Zhang, L., and Yang, W., 2008, Petroleum systems of the oldest gas field in China: Neoproterozoic gas pools in the Weiyuan gas field, Sichuan Basin: Marine and Petroleum Geology, v. 25, p. 371-386, doi: 10.1016/j.marpetgeo.2008.01.009. 
334 West, R.R. and Sutton W.J., 1954, Thermography of Gypsum: Trans. Central Geol. 335 Prospecting Znst (USSK), v. 88, p. 1-66.

336 Wignall, P.B., 2001, Large igneous provinces and mass extinctions: Earth-Science Reviews, v. 53, p. 1-33, doi: 10.1016/S0012-8252(00)00037-4.

Zhou, M.-F., Malpas, J., Song, X.-Y., Robinson, P.T., Sun, M., Kennedy, A.K., Lesher, C.M., and Keays, R.R., 2002, A temporal link between the Emeishan large igneous province (SW China) and the end-Guadalupian mass extinction: Earth and Planetary Science Letters, v. 196, p. 113-122, doi: 10.1016/S0012821X(01)00608-2. 
Fig 1. Volume of erupted basalt from Courtillot and Renne (2003) vs percentage of generic extinctions (from Rhodes and Muller 2005) for major LIPs. Two main populations of LIPs are evident, one for which the associated rate of extinction is close to the background rate (Columbia River to Ontong Java) and another for which the rate is far higher. Those in the latter group intrude sedimentary rocks that released abundant greenhouse or toxic gases.

Fig 2. Theoretical thermal profile in a Panzhihua-like contact aureole. The horizontal bars indicate the maximum distance into the aureole where the metamorphic reactions take place. The black portion of each bar represents the proportion of gas released by the reaction. 
Fig. 1

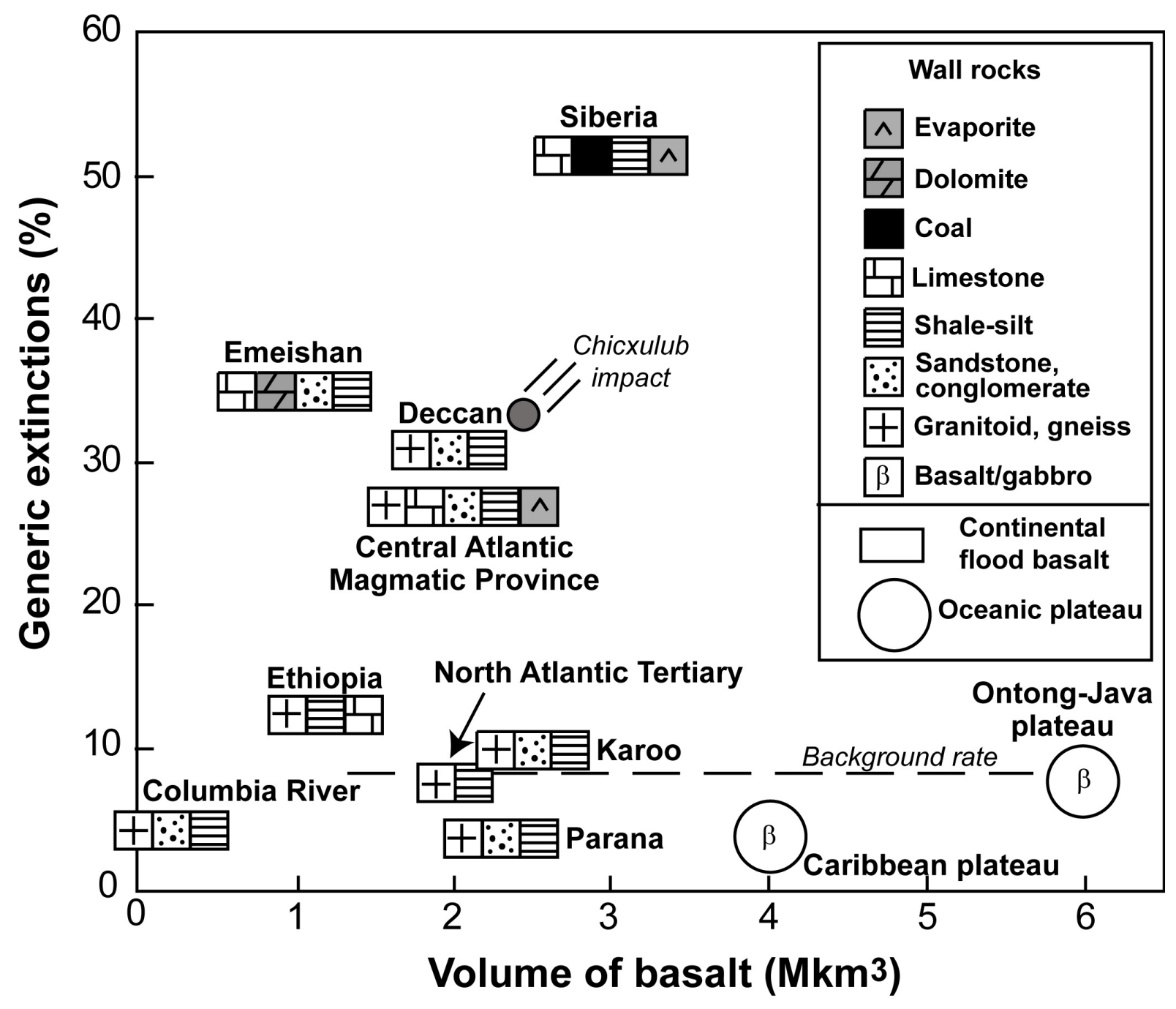


Fig. 2

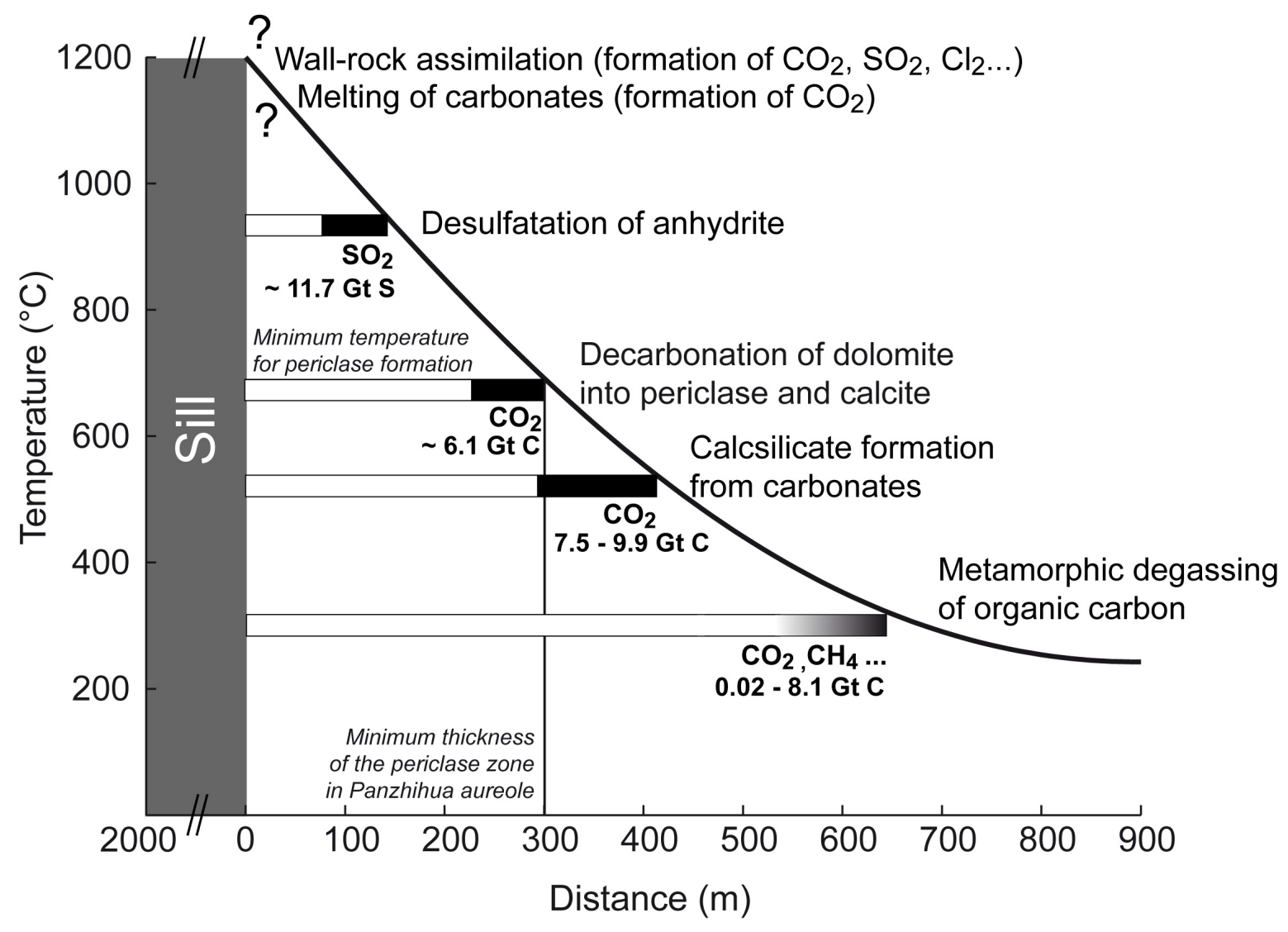



an explanation of the negative carbon isotope excursion associated with the emplacement of the Emeishan LIP

Our measurements of the $\delta^{13} \mathrm{C}$ of dolostones from the Sinian formation range from +4.7 to -1.1 , values which are consistent with Jacobsen and Kaufman's (1998) estimate of $\delta^{13} \mathrm{C}$ in Neoproterozoic seawater $(+4$ to $-4 \%$, with most of the data between +2 and -2 $\%$ o). If we assume that (1) end-Guadalupian seawater contained $\sim 40000 \mathrm{Gt} \mathrm{C}$ with $\delta^{13} \mathrm{C}$ $=+5 \%$ (Berner, 2005), (2) end-Guadalupian atmosphere contained $\sim 2850 \mathrm{Gt} \mathrm{C}$ (Rothman 2002) with $\delta^{13} \mathrm{C}=-2 \%$ (7\%o more negative than seawater (Mora et al. 1996)), then the average $\delta^{13} \mathrm{C}$ of the ocean-atmosphere system was +4.5 .

After the addition of $16800 \mathrm{Gt}$ of magmatic $\mathrm{CO}_{2}\left(4580 \mathrm{Gt} \mathrm{C}\right.$ with $\left.\delta^{13} \mathrm{C}=-6\right)$, $62500 \mathrm{Gt}$ of $\mathrm{CO}_{2}$ from destabilized Sinian dolostone $\left(17000 \mathrm{Gt} \mathrm{C}\right.$ with $\left.\delta^{13} \mathrm{C}=0\right)$ and potentially $84000 \mathrm{Gt} \mathrm{CO}_{2}$ from the metamorphism of organic carbon (=22900 $\mathrm{Gt} \mathrm{C}$ with $\delta^{13} \mathrm{C} \sim-22$ ), the bulk composition of the ocean-atmosphere system is changed to between $\delta^{13} \mathrm{C}=+2.6 \%$ (if no organic contribution) and -3.9 (if $22900 \mathrm{Gt} \mathrm{C}$ from the metamorphism of organic carbon was added with $\left.\delta^{13} \mathrm{C} \sim-22\right)$. If we then assume that ocean-atmosphere equilibrium is rapid (flux $\sim 90 \mathrm{Gt} / \mathrm{y}$ as current estimation) and the difference between the carbon isotope compositions of ocean and atmosphere is fixed at the timescales we consider $\left(\delta^{13} C_{a t m}=\delta^{13} C_{o c e a n}-7 \%\right.$ ), as supposed by Mora (1996) and Beerling et al. (2002), then the effect of emplacement of the Emeishan LIP in the Sinian Basin is a negative carbon excursion for the ocean-atmosphere system from an average of $\delta^{13} \mathrm{C}=-2$ before the degassing to an average of $\delta^{13} \mathrm{C}=-4.4$ to -10.9 after degassing.

\section{References cited}

Beerling, D.J., Lake, J.A., Berner, R.A., Hickey, L.J., Taylor D.W., and Royer D.L., 2002, Carbon isotope evidence implying high $\mathrm{O}_{2} / \mathrm{CO}_{2}$ ratios in the PermoCarboniferous atmosphere. Geochimica et Cosmochimica Acta, v. 66, p. 37573767, doi: 10.1016/S0016-7037(02)00901-8.

Berner, R.A., 2005, The carbon and sulphur cycles and atmospheric oxygen from middle Permian to middle Triassic: Geochimica et Cosmochimica Acta, v. 69,p. 3211-3217, doi: 10.1016/j.gca.2005.03.021.

Jacobsen, S.B., and Kaufman, A.J., 1999, The Sr, C and O isotopic evolution of Neoproterozoic seawater: Chemical Geology, v. 161, p. 37-57, doi: 10.1016/S0009-2541(99)00080-7.

Mora, C.I., Driese, S.G., and Colarusso, L.A., 1996, Middle to Late Paleozoic Atmospheric $\mathrm{CO}_{2}$ Levels from Soil Carbonate and Organic Matter: Science, v. 271, p. 1105-1107, doi: 10.1126/science.271.5252.1105. 

aureole in a sedimentary basin

The amount of gas released during metamorphism depends on the type of sediment and its chemical composition, and on the conditions (P,T, Xfluid) of metamorphism.

- At the highest temperatures, calcite melts incongruently to $\mathrm{CaO}$ and $\mathrm{CO}_{2}$. Solid or liquid calcite is assimilated into the magma where it reacts to $\mathrm{Ca}$ which is absorbed in the magma or overlying rocks and $\mathrm{CO}_{2}$, which degasses.

- Thermal decomposition of pure anhydrite $\left(\mathrm{CaSO}_{4}=\mathrm{CaO}+\mathrm{SO}_{2}+1 / 2 \mathrm{O}_{2}\right)$ begins at $1100^{\circ} \mathrm{C}$ and reacts readily only at temperatures around $1400{ }^{\circ} \mathrm{C}$. Impure anhydrite containing clay, graphite or carbon monoxide reacts at temperatures well below $1000^{\circ} \mathrm{C}\left(2 \mathrm{CaSO}_{4}+\mathrm{C}=2 \mathrm{CaO}+\mathrm{CO}_{2}+2 \mathrm{SO}_{2}\right.$ and $\mathrm{CaSO}_{4}+\mathrm{CO}=\mathrm{CaO}+\mathrm{CO}_{2}+$ $\mathrm{SO}_{2}$ ). Kuusik et al. (1985) report thermal decomposition of anhydrite in $\mathrm{CO} / \mathrm{N}$ mixtures at $900{ }^{\circ} \mathrm{C}$. Impurities such as $\mathrm{SiO}_{2}$ lower the decomposition temperatures by up to $100{ }^{\circ} \mathrm{C}$. West and Sutton (1954) report decomposition of anhydrite with $20 \%$ added carbon at $615^{\circ} \mathrm{C}$ in a nitrogen atmosphere.

- Thermal decomposition of pure limestone $\left(\mathrm{CaCO}_{3}=\mathrm{CaO}+\mathrm{CO}_{2}\right)$ strongly depends on the water content. In the absence of water, decomposition starts only at high temperature, around $1200^{\circ} \mathrm{C}$; when aqueous fluid is present, the temperature is lower $\left(\sim 700^{\circ} \mathrm{C}\right)$.

- Dolomite reacts to calcite, periclase and $\mathrm{CO}_{2}\left(\mathrm{CaMg}\left(\mathrm{CO}_{3}\right)_{2}=\mathrm{CaCO}_{3}+\mathrm{MgO}+\right.$ $\left.\mathrm{CO}_{2}\right)$ at $700^{\circ} \mathrm{C}$. In the presence of aqueous fluid the temperature decreases to below $\sim 450^{\circ} \mathrm{C}$

- Calc-silicates containing forsterite and diopside form from impure limestones and marls. These reactions release considerable $\mathrm{CO}_{2}$ and proceed at relatively low temperatures, between 450 and $500^{\circ} \mathrm{C}$.

- Organic matter in carbonates or shales releases $\mathrm{CH}_{4}$ and/or $\mathrm{CO}_{2}$. Cracking of hydrocarbons starts at $\sim 100^{\circ} \mathrm{C}$ and reaches a maximum around $550{ }^{\circ} \mathrm{C}$.

- Other gases are released from specific sediment types. Salts break down to halogens; pyrite in sulfide-rich shales oxidises or breaks down to Fe-oxide releasing sulfur oxides; coal burns to release $\mathrm{CO}_{2}$.

The reactions within an aureole thus release a series of greenhouse or toxic gases, including $\mathrm{CO}_{2}, \mathrm{SO}_{2}, \mathrm{CH}_{4}$, and halogens, as summarized in Figure 2.

References cited

Kuusik, R., Saikkonen, P., and Niinisto, L., 1985, Thermal decomposition of calcium sulfate in carbon monoxide: Journal Thermal Analysis and Calorimetry, v. 30, p. 187-193. 